\title{
Acute eosinophilic pneumonia secondary to heroin inhalation
}

\author{
Damla EYÜPOĞLU 1 \\ Ebru ORTAÇ ERSOY ${ }^{2}$ \\ Kazım ROLLAS ${ }^{1}$ \\ Arzu TOPELi ${ }^{1}$
}

${ }^{1}$ Department of Internal Medicine, Faculty of Medicine, Hacettepe University, Ankara, Turkey

${ }^{1}$ Hacettepe Üniversitesi Tıp Fakültesi, Iç Hastalıkları Anabilim Dalı, Ankara, Türkiye

2 Intensive Care Unit, Faculty of Medicine, Hacettepe University, Ankara, Turkey

2 Hacettepe Üniversitesi Tıp Fakültesi, Yoğun Bakım Ünitesi, Ankara, Türkiye

\section{SUMMARY}

\section{Acute eosinophilic pneumonia secondary to heroin inhalation}

Smoking heroin (chasing the dragon), is a method of inhaling heroin via heating the drug on a tin-foil above a flame. It also has been associated both with the indirect effects of heroin overdose and with direct pulmonary toxicity. We describe a case of acute eosinophilic pneumonia secondary to heroin inhalation in our medical intensive care unit. She presented with fever, cough, dyspnea and pleuritic chest pain. Chest radiograph showed bilateral infiltrations. Examination of bronchoalveolar lavage fluid revealed significant eosinophilia. She was diagnosed with acute eosinophilic pneumonia. After heroin abstinence and corticosteroid therapy, remission was achieved rapidly and the patient was discharge on the fourth day of her hospital stay.

Key words: Eosinophilic pneumonia, heroin, chasing dragon, opiate abuse, dyspnea

\section{ÖZET}

\section{Eroin inhalasyonuna bağlı akut eozinofilik pnömoni}

Eroin inhalasyonu (ejderha avı), eroinin ince bir folyo üzerinde alevde ısıtılarak solunması methodudur. Bu durum hem eroin yüksek dozunun indirekt etkileri hem de direkt pulmoner toksisite ile ilişkilidir. Olgumuzda, iç hastalıkları yoğun bakım ünitesinde izlediğimiz eroin inhalasyonuna sekonder ekut eozinofilik pnömoni olgusunu tanımladık. Olgumuzdaki kadın hasta; ateş, öksürük, dispne ve plöretik göğ̈̈s ağrısı ile başvurdu. Akciğer radyografisinde, bilateral infiltrasyonlar mevcuttu. Bronkoalveoler lavaj sıvısında eozinofili hakim olan hastaya akut eozinofilik pnömoni tanısı konuldu. Eroin maruziyetinin kesilmesi ve kortikosteroid tedavi sonrasında hızlı şekilde remisyona giren hasta yatışının dördüncü gününde taburcu edildi.

Anahtar kelimeler: Eozinofilik pnömoni, eroin, opyoid kullanımı, dispne

\section{Yazışma Adresi (Address for Correspondence)}

Dr. Ebru ORTAÇ ERSOY

Hacettepe Üniversitesi Tıp Fakültesi, Yoğun Bakım Ünitesi, ANKARA - TURKEY

e-mail: ebru.ortac@hacettepe.edu.tr 


\section{INTRODUCTION}

Smoking heroin (chasing the dragon), is a method of inhaling heroin via heating the drug on a tin-foil above a flame (1). Heroin smoking can produce severe bronchospasm in asthmatics and also in individuals with no previous history of asthma (2). It also has been associated both with the indirect effects of heroin overdose and with direct pulmonary toxicity (3). Several cases of acute eosinophilic pneumonia associated with the heroin inhalation have been reported in literature before $(4,5)$. We describe a rare case of acute eosinophilic pneumonia secondary to heroin inhalation.

\section{CASE REPORT}

A 22-year-old female with a history of daily heroin inhalation for 2 months, presented to emergency service with severe dyspnea and fever. Her complaints had started 1 week before her current admission and diffuse pulmonary infiltration on a chest X-Ray had been detected in an out-patient clinic. Because her findings were consistent with respiratory tract infection, a therapy of benzathine-penicilin $\mathrm{g}$ had been initiated. During the antibiotherapy, she had persisted in heroin inhalation and her complaints had increased aggressively. She had applied to an emergency service with severe dyspnea and fever.

In the emergency service, the patient was febrile $\left(38.5^{\circ} \mathrm{C}\right)$, her pulse was 111 beats/min, blood pressure was $110 / 70 \mathrm{mmHg}$ and respiratory rate was 26 breaths/min. On her physical examination, she looked cachectic and confused. Her cardiological and abdominal examination was normal. Her central nervous system examination was intact. On auscultation, diffuse crackles and ronchii were heard. On room air, her arterial blood gas resulted as $\mathrm{pH}=$ 7.22, $\mathrm{PaO}_{2}=60 \mathrm{mmHg}, \mathrm{pCO}_{2}=66 \mathrm{mmHg}$ and Lactate $=2.2 \mathrm{mmol} / \mathrm{L}$. Patient was transferred to our medical intensive care unit (MICU) because of acute respiratory failure. Treatment had been started as inhaled broncohodilators, parenteral $40 \mathrm{mg}$ methylprednisolone and non-invasive mechanical ventilation (NIMV) support.

On her admission to our MICU, her physical examination was compatible with the emergency service. Her arterial blood gas on NIMV was $\mathrm{pH}=7.4$, $\mathrm{PaO}_{2}=71 \mathrm{mmHg}, \mathrm{pCO}_{2}=43 \mathrm{mmHg}$ and lactate $=0.7$. Her count of blood cells resulted as leukocytosis (27.5 $\times 10^{3} / \mu \mathrm{L}$ ) with $87 \%$ neutrophils and $1.3 \%$ eosinophils. Because diffuse infiltration was detected on her chest X-Ray, a thorax CT scan was performed and bilateral interstitial infiltration with ground glass opacity and consolidation areas were detected (Figure 1,2). For excluding heart failure, echocardiography was performed and resulted as normal left ventricular systolic functions. The patient was started on piperacilin-tazobactam and clarithromycin antibiotherapy. Also, parenteral steroid therapy (metylprednisolon $40 \mathrm{mg} /$ daily) was continued due to diffuse ronchi.

A large number of microbiological and immunological assessment of blood, stool and urine samples were performed and resulted all negative. Also viral antibody tests were negative. The patient was seronegative for human immunodeficiency virus (HIV). On the third day of admission, bronchoscopy was performed and revealed swollen reddened respiratory tract with diffuse purulent secretion. The leukocytes in the bronchoalveolar lavage (BAL) fluid were $6 \%$ eosinophils and BAL fluid cultures resulted as negative.

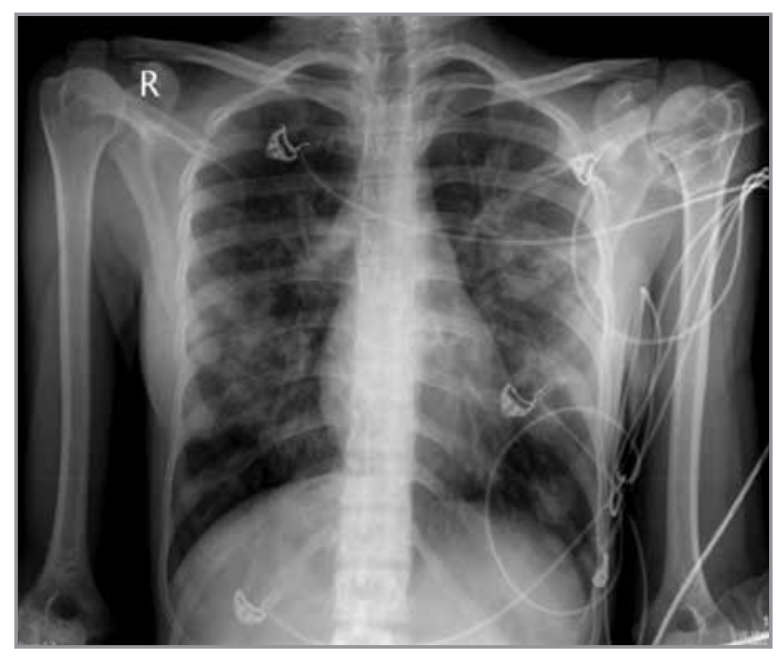

Figure 1. Chest X-Ray on the first day of the admission.

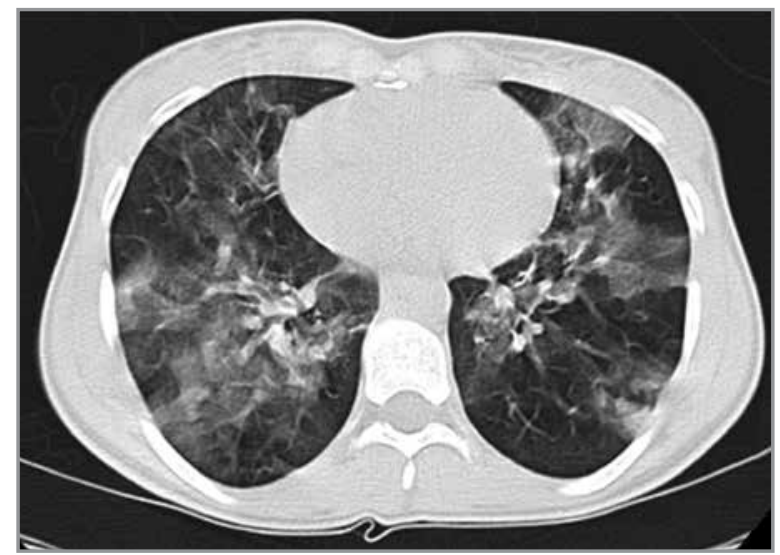

Figure 2. Thorax CT scan on the first day of the admission. 
The patient was diagnosed as acute eosinophilic pneumonia and after heroin abstinence and corticosteroid therapy, her lung functions developed dramatically and need of oxygen support decreased rapidly. On the fourth day after her admission, her laboratory and clinical findings normalized and the patient was discharged with the treatment of metylprednisolon with reducing schema.

A follow-up visit with a skin prick test, immunoglobulin E levels and lung function measurements was planned.

\section{DISCUSSION}

We describe a case of acute eosinophilic pneumonia secondary to heroin inhalation in our medical intensive care unit. She presented with fever, cough, dyspnea and pleuritic chest pain. Chest radiograph showed bilateral infiltration and bronchoalveolar lavage fluid revealed significant eosinophilia. She was diagnosed with acute eosinophilic pneumonia.

Inhalation of heroin is a popular method among heroin addicts (6). Chasing is quite an effective route of heroin administration, producing rapid, doserelated subjective and objective effects and a sufficiently high and reproducible bioavailability (7). Inhaled heroin inhalation produced clear dose-related changes on each of these dimensions, including stepwise, dose-related increases in subjective drugliking, body temperature and heart rate and the doses showed a clear and decline in reaction time (7).

Heroin is known to cause mast cell degranulation and release of histamine and other preformed mediators of inflammation (8). It was mentioned that there was a relation between heroin use by chasing the dragon and an impaired lung function (3). Acute eosinophilic pneumonia was described as pulmonary infiltrations of the lung by eosinophils that may or may not be accompanied by an excess of these cells in the peripheral blood (9). Diffuse pulmonary infiltrates on the chest radiograph, with an increased number of eosinophils detected by BAL and/or lung biopsy, indicate the diagnosis (10). Drug induced eosinophilic pneumonia usually resolves rapidly after discontinuation of the causative agent.4 In the majority of these cases there was no peripheral blood eosinophilia (11).

In our patient, 2 months of heroin inhalation may lead to decrease lung functions. The rapid clinical recovery and development in oxygen dependence after steroid therapy and discontinuation of chasing underscores the relationship. When BAL was performed, the patient had been already receiving 40 mg metylprednisolon therapy for 3 days and her clinical respiratory functions had normalized. The eosinophil count of BAL fluid had probably decreased from the initial levels.

\section{CONCLUSION}

This is a rare case report of heroin inhalation induced acute eosinophilic pneumonia. Clinicians must be aware of it, in the course of evaluating acute respiratory failure in drug addicts because of the increasing prevalence of heroin inhalation.

\section{REFERENCES}

1. Strang J, Griffiths P, Gossop M. Heroin smoking by 'chasing the dragon': origins and history. Addiction 1997;92.6:67384 .

2. Hughes $S$, Calverely PMA. Heroin inhalation and asthma. $\mathrm{Br}$ Med J 1988;297:1511-2.

3. Buster M, Rook L, van Brussel GH, van Ree J, van den Brink W. Chasing the dragon, related to the impaired lung function among heroin users. Drug Alcohol Depend 2002;68:221-8.

4. Brander PE, Tukiainen P. Acute eosinohilic pneumonia in a heroin smoker. Eur Respir J 1993;6:750-2.

5. Tsapas A, Patelas K, Vlachaki E, Bekiari E, Spanos C, Economidis D. et al. Eosinophilic pneumonia associated with heroin inhalation: a cese report. Wien Klin Wochenschr 2008; 120/5-6:178-80.

6. Gossop M. Griffiths P, Strang J. Chasing the dragon: characteristics of heroin chasers. Br J Addict 1988;83:115962.

7. Hendriks VM, van den Brink W, Blanken P, Bosman IJ, van Ree JM. Heroin self-administration by means of "chasing the dragon": pharmacodynamics and bioavailability of inhaled heroin. European Neuropsychopharmacology 2001;11:24152.

8. Withington DE, Patrick JA, Reynolds F. Histamine release by morphine and diamorphine in man. Anaesthesia 1993;48:26-9.

9. Liebow AA, Carrington CB. The eosinophilic pneumonias. Medicine 1969;48:252-85.

10. Badesh DB, King TE, Schwarz MI. Acute eosinophilic pneumonia: a hypersensitivity pnenomenon? Am Rev Respir Dis 1989;139:249-52.

11. Alien JN, Pacht ER, Gadek ffi, Davis WB. - Acute eosinophilic pneumonia as a reversible cause of noninfectious respiratory failure. N Engl I Med 1989;321:569-74. 